\title{
National Medical Arbitration Commission: two decades of its formation
}

\author{
José Luis Sandoval-Gutiérrez
}

Department of Pulmonology, Instituto Nacional de Enfermedades Respiratorias Ismael Cosío Villegas, Ciudad de México, Mexico

De la Fuente $^{1}$ presents an editorial about his personal experience in the creation of the National Medical Arbitration Commission (CONAMED - Comisión Nacional de Arbitraje Médico). CONAMED was founded in $1996^{2}$ and, initially, the medical community was unaware of the reach this commission had; there was concern that an inquisitorial attitude by the experts might toughen the relationship with physicians.

Conciliation has been the weapon for a sound solution of conflicts. The need to maintain an adequate communication in the doctor-patient relationship is emphasized.

National epidemiology shows that population morbidity and mortality have changed, giving way to chronic-degenerative conditions as the cause of hospital admission and outpatient consultation.

The expectations of patients and their families have exponentially grown, and bad news and adverse prognoses, which were serenely accepted in the past, are therefore currently the cause of conflict ${ }^{3}$.

Technological and human resources limitations in hospital areas, which can be found with certain regularity especially at night shifts or weekends, are fertile ground for discussions and complaints.
CONAMED has taken care of diffusion and training for problem solving ${ }^{4,5}$, thus allowing that stakeholders, rather than lawyers' commercial interest, negotiate the less harmful conciliation.

It is necessary for physicians and the health team to be familiarized with this commission's recommendations, since potential cases of lawsuit are to be increased in the future.

Fair, respectful, moderate and empathic communication allows continuing with the necessary, though sometimes forgotten, doctor-patient relationship.

\section{References}

1. De la Fuente JR. La Comisión Nacional de Arbitraje Médico: 20 años. Gac Med Mex. 2016;152:726-9.

2. De la Fuente JR. Presentación de la Comisión Nacional de Arbitraje Médico. Gac Med Mex. 1996;132:357-8.

3. Recibió la Conamed 1,652 quejas por negligencia médica en 2010 . (Consultado el 20 de enero de 2017.) Disponible en: http://www.jornada. unam.mx/ultimas/2013/11/19/recibio-la-conamed-1-652-quejas-por-negligencia-medica-en-2010-4360.html.

4. CONAMED(Consultado el 13 de diciembre de 2017). Disponible en: https://www.gob.mx/conamed

5. Revista CONAMED. (Consultado el 23 de enero de 2017.) Disponible en: http://www.dgdi-conamed.salud.gob.mx/ojs-conamed/index.php/ revconamed.

\section{Correspondence:}

José Luis Sandoval-Gutiérrez

Tlalpan, 4502

Col. Sección XV

Date of reception: 29-01-2017

Date of acceptance: 02-02-2017

C.P. 06170, Ciudad de México, México

E-mail: sandovalgutierrez@gmail.com
DOI://dx.doi.org/10.24875/GMM.M18000096
Gac Med Mex. 2017;153:820-820

Contents available at PubMed www.gacetamedicademexico.com 